\title{
Empirical Study on the Path to Organizational Cultural Hegemony Construction
}

\author{
Yucai Zhong ${ }^{1, \text { a }}$ \\ ${ }^{1}$ College of Civil Engineering, Fuzhou University, Fuzhou 350116, China; \\ ayc@fzu.edu.cn
}

Keywords: organizational culture, cultural hegemony, policy quantification

\begin{abstract}
On the basis of Kathleen M. Eisenhardt's case construction theory [1] and Huang Cui's research methodology of quantification of policy documents[2], this paper takes the case of Huawei's organizational cultural hegemony construction. And through analysis of the contents of and correlation among 241 norms of Huawei's four internal normative documents with the widest use and the deepest influence, it discovers that Huawei's organizational culture is efficiently constructed by absolute control over Huawei's organization by the cultural hegemony subject, Huawei's power structure, well-defined core values and strict information spreading control. This proves that power, power structure, cultural communication and information spreading of the cultural hegemony subject are major influence factors of constructing cultural hegemony.
\end{abstract}

\section{Introduction}

According to Huawei's official website, Huawei was established as a sales agency for a Hong Kong company producing private branch exchanges (PBX) in 1987 with the registered capital of RMB 20,000. After development for nearly 30 years, Huawei has become a leading global information and communications technology (ICT) solutions provider. Currently, Huawei has about 180,000 employees in business premises covering over 170 countries and regions around the globe. In cooperation with its carriers, Huawei has built more than 1,500 networks around the world, helping more than one third of the world's population to be connected.

Organizational core values are cornerstones of organizational culture and they are organizational cultural genes which are extracted and put into practice by an organization to pursue its vision and fulfill its mission and which guide the whole organization in shaping a common behavioral pattern. Fighting-spirited culture is the most important and central part of Huawei's organizational culture and one of Huawei's core values. This paper will profoundly analyze how Huawei's fighting-spirited culture was shaped, so as to develop the shaping mechanism of organizational cultural hegemony.

\section{Methodology}

Data Source. This paper selects and analyzes in detail 241 norms from Huawei's four internal normative documents with the widest use and the deepest influence, namely Huawei Employee Code of Conducts, Huawei Basic Rules, Huawei Company Personnel Management System, and Huawei Performance Management and Evaluation System. See Table 1. Huawei Basic Rules sort out Huawei's organizational culture and thoughts with unified language in a centralized way by Huawei itself. They are also the first complete and systematic summarization of corporate culture by a Chinese enterprise and play a significant role in promoting corporate culture building in China.

Table 1 Distribution of Data Source

\begin{tabular}{ccccc}
\hline $\begin{array}{c}\text { Name of } \\
\text { Dormative }\end{array}$ & $\begin{array}{c}\text { Huawei } \\
\text { Employee } \\
\text { Code of } \\
\text { Conducts }\end{array}$ & $\begin{array}{c}\text { Huawei Basic } \\
\text { Rules }\end{array}$ & $\begin{array}{c}\text { Huawei Company } \\
\text { Personnel } \\
\text { Management } \\
\text { System }\end{array}$ & $\begin{array}{c}\text { Huawei Performance } \\
\text { Management and } \\
\text { Evaluation System }\end{array}$ \\
\hline $\begin{array}{c}\text { Number of } \\
\text { Norms }\end{array}$ & 13 & 103 & 85 & 40 \\
\hline
\end{tabular}


Data Analysis Method. This paper first uses the policy instrument thought and theory of Rosevear and Ziegfeld as reference to see if these chosen Huawei rules and systems contain the major influence factors in the cultural hegemony model put forth herein (see Table 2) and calculate the quantity of data source. After that, this paper analyzes policy document contents one by one based on quantitative statistics of policy documents to find out the internal correlation among the four influence factors in policy documents.

Table 2 Classification of Major Influence Factors and Elements of Huawei’s Organizational Cultural Hegemony

\begin{tabular}{|c|c|c|c|c|c|c|c|c|c|c|c|}
\hline $\begin{array}{l}\text { Influe } \\
\text { nce }\end{array}$ & \multicolumn{2}{|c|}{ Subject power } & \multicolumn{2}{|c|}{ Power structure } & \multicolumn{5}{|c|}{ Subject culture } & \multicolumn{2}{|c|}{$\begin{array}{c}\text { Information } \\
\text { spreading }\end{array}$} \\
\hline $\begin{array}{c}\text { Major } \\
\text { Eleme } \\
\text { nts }\end{array}$ & $\begin{array}{l}\text { Organizat } \\
\text { ional } \\
\text { power }\end{array}$ & $\begin{array}{c}\text { Econo } \\
\text { mic } \\
\text { interes } \\
\text { ts }\end{array}$ & $\begin{array}{c}\text { Organizat } \\
\text { ional } \\
\text { power } \\
\text { distributi } \\
\text { on ways }\end{array}$ & $\begin{array}{c}\text { Econo } \\
\text { mic } \\
\text { interest } \\
s \\
\text { distribu } \\
\text { tion } \\
\text { ways }\end{array}$ & $\begin{array}{c}\text { Val } \\
\text { ue } \\
\text { cult } \\
\text { ure }\end{array}$ & $\begin{array}{c}\text { Inter } \\
\text { est } \\
\text { cultu } \\
\text { re }\end{array}$ & $\begin{array}{l}\text { Mor } \\
\text { al } \\
\text { cult } \\
\text { ure }\end{array}$ & $\begin{array}{c}\text { Aesth } \\
\text { etic } \\
\text { cultur } \\
\text { e }\end{array}$ & $\begin{array}{l}\text { Life } \\
\text { cult } \\
\text { ure }\end{array}$ & $\begin{array}{c}\text { Informa } \\
\text { tion } \\
\text { circulat } \\
\text { ion }\end{array}$ & $\begin{array}{c}\text { Informa } \\
\text { tion } \\
\text { circulat } \\
\text { ion } \\
\text { prohibit } \\
\text { ion }\end{array}$ \\
\hline
\end{tabular}

For the convenience of analyzing documents, this chapter classifies the element contents corresponding to the four influence factors, i.e. subject power, subject power structure, subject culture and information spreading, into A, B, C and D categories. For example, Article 5 in Huawei Basic Rules specifies that "we will never allow contributors to suffer loss and givers will definitely get reasonable paybacks." This article mainly elaborates Huawei's interest culture preference. Article 84 in Huawei Company Personnel Management System sets forth that the Company opposes any employee's corrupt life and prohibits any employee from participating in any activity that wears down his/her willpower like playing mahjong and any activity in violation of the laws, statutes and regulations of China. This article shows Huawei's life culture preference. Therefore, both of these articles are marked as "C". Article 23 in Huawei Basic Rules stipulates that "we adhere to the principle of excelling. We shall distribute resources to the extent of surpassing our major competitors in terms of key factors for success and chosen strategic growth points. Take it or leave it. If we take it, we shall make major breakthroughs by greatly centralizing human, material and financial resources. We shall make efforts to eliminate any obstacle in resource distribution and effective use. We realize that the distribution of excellent talents is foremost in the distribution of these three key resources, namely human, material and financial resources. It is our guideline to enable the most excellent people to accomplish the tasks assigned to them with adequate authority and necessary resources." This article highlights organizational power and economic interest distribution ways of the organization, so it is marked as "B". To give another example, Article 64 in Huawei Company Personnel Management System provides that "anyone under any of the following circumstances shall be demoted: ... (III) anyone who spreads any rumor to the disadvantage of the Company or sow dissension between the Company and any other employee with minor influence ..." This article involves Huawei's rules about subject power control and information circulation prohibition, so this document is marked as " $\mathrm{A}$ " and " $\mathrm{D}$ ". Moreover, for the convenience of elaboration, we classify and mark specific text analysis units. For example, Article 1 in Huawei Employee Code of Conducts is marked as "1.1"; Article 1 in Huawei Basic Rules is marked as "2.1"; Article 1 in Huawei Company Personnel Management System is marked as "3.1" and Article 1, Chapter 1 in Huawei Performance Management and Evaluation System is marked as "4.1.1".

Data Analysis Process. 46 out of 241 norms from Huawei Employee Code of Conducts, Huawei Basic Rules, Huawei Company Personnel Management System and Huawei Performance Management and Evaluation System are related to Huawei's company power, taking up 19\% of the analysis text. This paper finds out through in-depth analysis of category-A text content analysis units that Huawei puts great emphasis on the organization's absolute control. For example, Huawei expressly states that it "maintains control in any form of cooperation involving Huawei's logos" 
(2.40); "Huawei's company president has the final decision" (2.53) and Huawei "denies any anarchical, disorganized and indiscipline individualistic behavior fundamentally" (2.59).

129 out of 241 norms from Huawei Employee Code of Conducts, Huawei Basic Rules, Huawei Company Personnel Management System and Huawei Performance Management and Evaluation System are related to Huawei's power structure, accounting for $54 \%$ of analysis text. For encouraging its employees to work hard, Huawei stipulates in explicit terms that "the Company gives priority to efficiency and each employee is expected to fight for the opportunities provided by the Company by virtue of his/her hard work and capability" (2.57); "anyone who has taken risks to accomplish his/her tasks and made achievements shall be recognized" (3.59); any employee "who is dedicated to continuous improvement of his/her work" to the extent of setting a good example in the Company shall be conferred a special award (3.60). For excellent hard workers, Huawei "unswervingly provides favored policies to excellent employees in terms of remunerations and compensations" (2.69). For example, Huawei expressly states that "it will bring the most conscientious and talented people into the Company's backbone force" $(2.17,2.19)$ through favored distribution of capital and equities. Besides, Huawei also emphasizes that members of its senior management shall "insist in putting the Company's interests higher than department and personal interests" (2.54). On the other hand, to prevent employee sluggishness, Huawei "establishes routine employment contract termination and employee dismissal procedures by taking advantage of the competition and elimination mechanism of its internal labor market" (2.68); "sequential order of employee severance: employees with low average rating in performance evaluation over the years; employees with low working efficiency; employees with short length of service for the Company and poor competence" (3.73). Huawei's performance evaluation system has played a critical role in the development of its fighting-spirited culture. Performance evaluation is used to appraise whether an employee or manager is an excellent fighter. Therefore, Huawei stipulates detailed provisions for its performance evaluation system in Articles 3.55, 2.85, 4.1.8, 4.2.2, 4.2.3, 4.2.6, 4.3.2-4.3.18 of its rules and systems. Moreover, the linkage between the use of performance evaluation and rewards and punishments enables the fightingspirited culture stands on an advantageous point in competition. Such culture will eventually guide employees to become fighters and shape the organizational fighting-spirited culture.

58 out of 241 norms from Huawei Employee Code of Conducts, Huawei Basic Rules, Huawei Company Personnel Management System and Huawei Performance Management and Evaluation System are related to Huawei's company fighting-spirited culture, taking up $24 \%$ of analysis text. Huawei puts forward requirements for all of its employees that they "shall keep improving their working skills and strengthening their quality awareness to successfully accomplish their tasks assigned by their leaders at all levels" (3.12); "if the Company wants to arrange business trips for employees based on its needs, such dispatched employees shall obey such arrangement unless they have special reasons" (3.34). This indicates the direction for making efforts and working hard for Huawei's employees.

20 out of 241 norms from Huawei Employee Code of Conducts, Huawei Basic Rules, Huawei Company Personnel Management System and Huawei Performance Management and Evaluation System are related to Huawei's company information spreading, taking up 8\% of analysis text. On one hand, Huawei spreads its culture in an in-depth way through trainings, system learning, recognition of advanced people, publicity and reporting in its internal publications, etc. On the other hand, Huawei poses extremely strict limitation on its information spreading. For example, Huawei's employees are expected to remember and "develop a prevailing practice of hardworking" at any time (1.6), to "safeguard the Company's security and image consciously" (1.7 and 1.8) and not to "inquire about, conjecture or participate in spreading of gossips" (2.49). Huawei has built its fighting-spirited culture effectively through its rigid control over cultural information.

\section{Results and Discussion}

Through content analysis of 241 norms from Huawei's four internal normative documents with the widest use and the deepest influence, this paper finds out that a principal thread always runs through Huawei's cultural hegemony construction, i.e. Huawei's value production and distribution chain. Clarification of such issues as the social value of Huawei's existence, for whom Huawei creates value, 
who is benefited from Huawei's value, how to enable Huawei to create value with all of its strength and how to evaluate and distribute value in a scientific way gives guidance for shaping Huawei's organizational culture (See Fig.1).

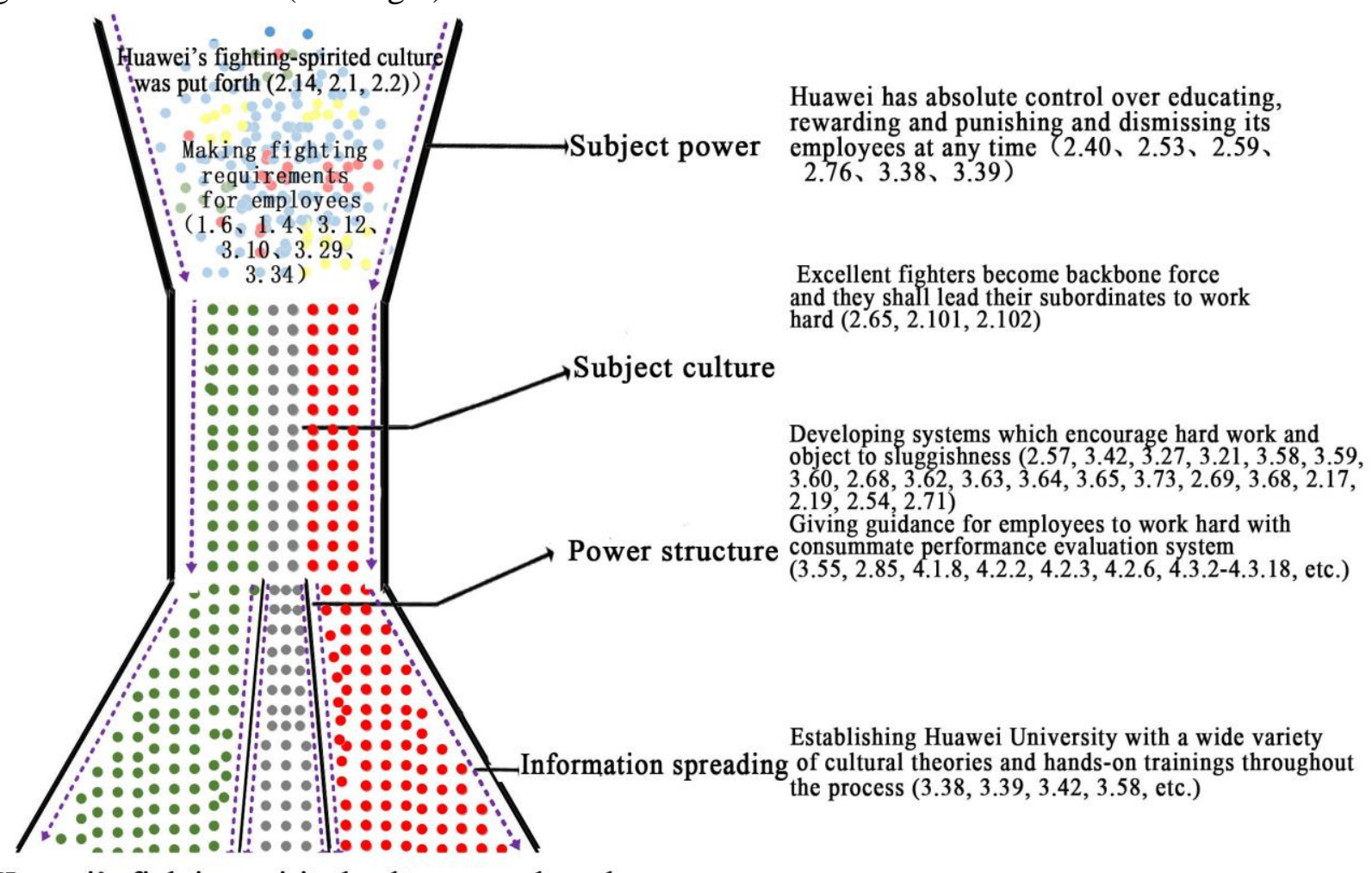

Huawei's fighting-spirited culture was shaped

\section{Conclusion}

Fig. 1 Huawei’s Cultural Hegemony Construction Path

Through analysis of the contents of and correlation among 241 norms from Huawei's four internal normative documents with the widest use and the deepest influence, this paper finds out that importance attached to organizational subject power building and effective control over organizational resources are cornerstones of building organizational culture; scientific organizational power structure and effective management systems are guaranty for building organizational culture; clear organizational culture and well-defined realization ways are fundamental to realizing goals of organizational culture; importance attached to cultural information spreading to allow implementation of organizational culture is the foothold of building organizational culture. Huawei's effective construction of its organizational culture proves that power, power structure, cultural communication and information spreading of the cultural hegemony subject are major influence factors of constructing cultural hegemony and they provide empirical proof of the cultural hegemony shaping path put forth herein.

\section{Acknowledgment}

This article was supported by the Foundation of Fuzhou University of China.

\section{References}

[1] Li Ping, Cao Yangfeng. The method of case study: Theory and example -- selected articles by Kathleen M. Eisenhardt. [M]. Beijing: Peking University press.2012.

[2] Huang Cui.Research on Quantification of Policy Documents. [M]. Beijing: Science Press.2016. 